\title{
GMR
}

\section{Polymorphisms in GJA1 and their association with growth traits in chicken}

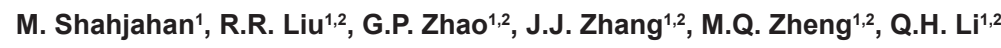 \\ and J. Wen ${ }^{1,2}$ \\ ${ }^{1}$ Institute of Animal Sciences, Chinese Academy of Agricultural Sciences, \\ Beijing, China \\ ${ }^{2}$ State Key Laboratory of Animal Nutrition, Beijing, China \\ Corresponding author: J. Wen \\ E-mail: jiewen@iascaas.net.cn \\ Genet. Mol. Res. 14 (4): 18839-18850 (2015) \\ Received August 7, 2015 \\ Accepted October 29, 2015 \\ Published December 28, 2015 \\ DOI http://dx.doi.org/10.4238/2015.December.28.33
}

ABSTRACT. This study aimed to screen single nucleotide polymorphisms (SNPs) in the chicken gap junction protein alpha 1 (GJA1) gene, and to investigate their association with five growth traits measured in 269 chickens encompassing Chinese indigenous Beijing-You (BJY) and commercial Cobb broiler (CB) populations. Four variants were detected in the chicken GJA1 gene, in which one synonymous mutation was located in an exon (C61223231T or C. $-1110 \mathrm{C}>\mathrm{T}$ ), two in an intron (A61229799C or c.5460 A >C, T61229928A or c.5589 T>A) and one in the promoter (A61230599C or C. $6260 \mathrm{~A}>\mathrm{C}$ ) regions. Genotyping was performed by high-resolution melting analysis (SNP in an exon) and DNA sequencing (SNP in the introns and promoter). Association analysis revealed that each SNP had a significant effect on growth traits in chicken. A higher level of genetic diversity was observed in the indigenous BJY breed than in the commercial CB breed. Strong linkage disequilibrium was observed between the C61223231T and A61229799C polymorphisms, and four previously undiscovered haplotypes (CA, TC, CC, TA) were constructed from those two mutations. Association analysis between haplotype combinations (diplotypes) and growth traits was highly significant where diplotype $\mathrm{CC}+\mathrm{CC}$ was dominant for all traits. 
We speculated that GJA1 either is a major gene, or is associated with a major gene, affecting chicken growth traits. Therefore, further studies are needed in large populations to evaluate polymorphisms located in different regions of this gene, as well as its functional study, to better understand its role in muscle development in chicken.

Key words: Chicken; GJA1; Polymorphisms; Growth traits; Association; Diplotype

\section{INTRODUCTION}

The improvement of growth traits is of utmost importance in the meat industry to enable producers to meet the enormous global demand for meat. The use of traditional animal breeding programs to improve favorable traits would be difficult as such traits are complex and under the control of multiple genes. A greater understanding of the genetic basis of these traits is needed to efficiently lead the genetic improvement of livestock species including chicken (Sun et al., 2013) through marker-assisted selection (MAS). Therefore, much emphasis has been placed on the investigation of genetic markers (Dodgson et al., 1997; Vignal et al., 2002) for the rapid advancement of molecular genetics. Single nucleotide polymorphisms (SNPs) are one such marker, which are used to map complex traits by linkage disequilibrium (LD) when they are linked to the gene of interest (Emara and Kim, 2003).

Previous studies have identified several polymorphisms in different genes that are closely associated with growth traits in chicken. Variants of the adipose triglyceride lipase (ATGL), patatinlike phospholipase domain containing 3 (PNPLA3), and thyroid peroxidase (TPO) genes have been implicated in the body weight (BW) of chicken (Nie et al., 2010; Su et al., 2012; Hou et al., 2013). Mutations in the insulin-like growth factor 1 (IGF1), PNPLA3, and pituitary-specific positive transcription factor 1 (POU1F1) genes have been identified for the carcass weight (CW) trait (Sato et al., 2012; Su et al., 2012; Xu et al., 2012). Growth hormone secretagogue receptor (GHSR), PNPLA3, and POU1F1 genes have been recommended for the evisceration weight (EW) of chicken (Fang et al., 2010; Su et al., 2012; Xu et al., 2012), and the agouti related neuropeptide (AGRP) and TPO genes were identified for the traits breast muscle weight (BMW) and thigh muscle weight (TMW), respectively (Bai et al., 2012; Hou et al., 2013). Several quantitative trait loci (QTLs) have been investigated in different chromosomal regions of chicken for the BW (Kerje et al., 2003; Pinard-van der Laan et al., 2009), CW (Wang et al., 2012), and TMW (Nones et al., 2006) traits. A few genome wide association studies (GWAS) have also identified several loci on chromosomes 1 and 4 that are strongly associated with BW, CW, EW, BMW, and TMW traits (Gu et al., 2011; Xie et al., 2012; Liu et al., 2013) in chicken. However, a limited number of genetic markers invested on chromosome 3 either by QTL or GWAS for growth traits in chicken. Our previous study identified eight SNPs within a $0.65 \mathrm{Mb}$ region on chromosome 3 which were nearest to gap junction protein alpha 1 (GJA1) gene and closely associated with chicken BMW and breast muscle percentage (BMP) (Liu et al., 2013).

GJA1 encodes one of the most abundant connexin proteins, connexin43 (Cx43), which has a molecular weight of $43 \mathrm{kDa}$. Polymorphisms in the GJA1 gene and their associations have been identified in human nonsyndromic deafness (hearing loss), anomalies in eye, tooth, cleft lip, and digit formation (Amano et al., 2012), as well as palmoplantar keratosis disease in patients with oculo-dento-digital dysplasia (Kogame et al., 2014). No polymorphisms in the GJA1 gene 
that may affect economic traits in chicken have been investigated. Therefore, this study was planned to investigate SNPs in the GJA1 gene and their associations with growth traits in order to evaluate the effect of this gene on muscle growth in chicken. This will provide further useful and detailed information that can be used to advance poultry breeding by molecular marker-assistant selection programs.

\section{MATERIAL AND METHODS}

\section{Ethics statement}

The chicken populations in this experiment were used in accordance with the Guidelines for Experimental Animals established by the Ministry of Science and Technology (Beijing, China).

\section{Chickens and growth trait measurements}

Two chicken populations were used in the present study: Beijing-You (BJY) and Cobb ( $\mathrm{CB}$, Cobb-Vantress, Inc.) chickens. BJY is a slow growing Chinese indigenous chicken breed and $\mathrm{CB}$ is a fast growing commercial broiler strain. All birds (male) were hatched on the same day and raised in stair-step cages under the same recommended environmental and nutritional conditions at the conservation farm of the Institute of Animal Sciences (IAS), CAAS. Before slaughtering at 90-days of age, birds were fasted for $12 \mathrm{~h}$. Blood was collected from a wing vein of 158 BJY and $111 \mathrm{CB}$ chickens by venipuncture using citrated syringes during a routine health inspection. Blood samples were stored at $-20^{\circ} \mathrm{C}$ until gDNA extraction was performed. The body weight of chickens was measured before the slaughtering procedure was executed by stunning and exsanguination. The growth traits including BW, CW (including feet and head), eviscerated weight (EW), BMW (both sides, including pectoralis major and minor), and TMW (both sides, deboned), were recorded and measured, as described by Li et al. (2009).

\section{Genomic DNA extraction and mutational screening of GJA1}

Genomic DNA was extracted from each $30-\mu \mathrm{L}$ blood sample by the standard phenol chloroform method. The concentration of DNA was determined by NanoDrop 2000 (Thermo, Waltham, MA, USA). To identify SNPS in the GJA1gene, the following primers were designed according to the DNA sequences (Table 1) (GenBank accession No. NC_006090.3 containing GI: 395278) using Primer Premier 5 software. Each DNA pool was prepared from 20 randomly selected individuals of each breed (50 ng DNA) for initial screening by sequencing the amplicons obtained by polymerase chain reaction (PCR). The $20-\mu \mathrm{L}$ reaction volume included $10 \mu \mathrm{L} 2 \mathrm{X}$ Taq PCR Master Mix (Tiangen, Beijing, China) containing $500 \mu \mathrm{M}$ dNTPs each, $20 \mathrm{mM}$ Tris-HCL, 100 $\mathrm{mM} \mathrm{KCl}, 3 \mathrm{mM} \mathrm{MgCl}$, and $1 \mu \mathrm{L}$ gDNA template $(50 \mathrm{ng} / \mu \mathrm{L}), 7 \mu \mathrm{L} \mathrm{ddH} 2 \mathrm{O}$, and $1 \mu \mathrm{L}$ each primer $(10$ $\mathrm{pM} / \mu \mathrm{L})$. The PCR cycling program was performed with an initial denaturation cycle at $95^{\circ} \mathrm{C}$ for 5 min followed by 32 cycles of $95^{\circ} \mathrm{C}$ for $30 \mathrm{~s}, 60^{\circ} \mathrm{C}$ for $30 \mathrm{~s}$, and $72^{\circ} \mathrm{C}$ for $30 \mathrm{~s}$, and ending with an extension cycle at $72^{\circ} \mathrm{C}$ for $5 \mathrm{~min}$. The purified PCR products were sequenced commercially using an ABI3730XL sequencer (Beijing Tianyi Huiyuan Bioscience and Technology Inc., Beijing, China).

\section{Genotyping by DNA sequencing and high-resolution melting (HRM) analysis}

Three pairs of primer were designed to genotype mutations in the GJA1, where one pair 
was considered for the C61223231T variant (HRM analysis) located in an exon of this gene (Table 2). The $25-\mu \mathrm{L}$ PCR mixture included $2.5 \mu \mathrm{L}$ 10X PCR buffer ( $\mathrm{Mg}^{2+}$ plus), $2 \mu \mathrm{L} 2.5 \mathrm{mM}$ dNTP mixture,

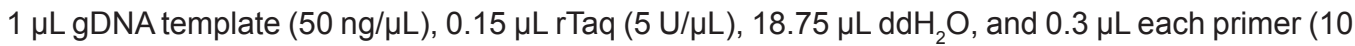
$\mathrm{pM} / \mu \mathrm{L})$. The reaction was performed with an initial denaturation cycle at $95^{\circ} \mathrm{C}$ for 5 min followed by 35 cycles of $94^{\circ} \mathrm{C}$ for $15 \mathrm{~s}, 60^{\circ} \mathrm{C}$ for $30 \mathrm{~s}$, and $72^{\circ} \mathrm{C}$ for $30 \mathrm{~s}$, and ended with an extension cycle at $72^{\circ} \mathrm{C}$ for $10 \mathrm{~min}$. Next, the PCR samples obtained for each individual were genotyped for SNP sites by a commercial sequencing company (Sino Geno Max Co., Beijing, China).

\begin{tabular}{|c|c|c|c|}
\hline Primers & Primer sequence $\left(5^{\prime}-3^{\prime}\right)$ & Length of product (bp) & Annealing temperature $\left({ }^{\circ} \mathrm{C}\right)$ \\
\hline Seq1 & $\begin{array}{l}\text { F: ATCGTTTCTCCGTGTCTCC } \\
\text { R: AAGTTGAGGGAAGTGTCGT }\end{array}$ & 1031 & 55 \\
\hline Seq2 & $\begin{array}{l}\text { F: TTTACGAGGTATCAGCACTT } \\
\text { R: CCCTTTACCGAGGTTGCT }\end{array}$ & 847 & 55 \\
\hline Seq3 & $\begin{array}{l}\text { F: TTTATGGGTTTAGCCTGAG } \\
\text { R: GCTATCCTACTTCCACCTAT }\end{array}$ & 1311 & 55 \\
\hline
\end{tabular}

For HRM analysis, the 20- $\mathrm{LL}$ PCR volume contained $10 \mu \mathrm{L} 2 \mathrm{X}$ Tag PCR Master Mix (Tuoyingfang, Beijing, China) including $0.5 \mathrm{mM}$ dNTPs each, $4 \mathrm{mM} \mathrm{MgCl}, 0.1$ units/ $\mu \mathrm{L}$ Tag DNA polymerase, and $1 \mu \mathrm{L}$ DNA template $(50 \mathrm{ng} / \mu \mathrm{L}), 6 \mu \mathrm{L} \mathrm{ddH}_{2} \mathrm{O}, 1 \mu \mathrm{L} \mathrm{LC}$ Green ${ }^{\text {PLus }}$ (Idaho Technology, Salt Lake City, Utah, USA), and $1 \mu \mathrm{L}$ each primer $(10 \mathrm{pM} / \mu \mathrm{L})$. The PCR products $(10$ $\mu \mathrm{L}$ ) from each sample were used for HRM analysis. The reaction was carried out with an initial denaturation cycle at $96^{\circ} \mathrm{C}$ for $5 \mathrm{~min}, 32$ cycles of $96^{\circ} \mathrm{C}$ for $30 \mathrm{~s}, 61.6^{\circ} \mathrm{C}$ for $30 \mathrm{~s}$ and $72^{\circ} \mathrm{C}$ for $30 \mathrm{~s}$, and an additional $5 \mathrm{~min}$ at $72^{\circ} \mathrm{C}$ as an extension cycle. HRM was performed on a LightScanner ${ }^{\mathrm{TM}}$ platform (Idaho Technology) within a temperature range of $55-95^{\circ} \mathrm{C}$ with a ramp rate of $0.10^{\circ} \mathrm{C} / \mathrm{s}$. Melting curve analysis was carried out using the LightScanner software package with CALL-IT ${ }^{\circledR}$ (Idaho Technology). Melting profiles were calibrated by internal oligonucleotide controls, and then normalized, grouped, and displayed as fluorescence-versus-temperature plots or subtractive difference plots (-df/dt vs T).

Table 2. Primer sequences, product size, and Tm values for genotyping of variants in GJA1 gene.

\begin{tabular}{llcc}
\hline Primer (target SNP) & Primer sequence $\left(5^{\prime}-3^{\prime}\right)$ & Length of product $(\mathrm{bp})$ & Annealing temperature $\left({ }^{\circ} \mathrm{C}\right)$ \\
\hline Seq1 (A61229799C) & F: AGTAAACAAAGCCGCACGAAC & 405 & 60 \\
Seq2 (T61229928A and A61230599C) & R: TGGAACACGAGCAGAGCTTTT & 422 & 60 \\
Seq3 (C61223231T for HRM) & R: AAAACCCGTAACCCACGTCT & & 61.6 \\
& F: CCATTGTGGACCAGAGGC & 70 & \\
\hline
\end{tabular}

\section{Statistical analysis}

The DNA sequences were assembled and analyzed using SeqMan II version 5.01 (DNAStar Inc., Madison, WI, USA). The genotypic and allelic frequencies, and Hardy-Weinberg equilibrium (HWE) of each SNP were statistically analyzed as previously described (Sun et al., 2013). LD ( $\left.r^{2}\right)$ was estimated by Haploview 4.1 (Barrett et al., 2005). Haplotypes were constructed based on SNPs using the Phase 2.0 program (Stephens et al., 2001). Genotypes and breed effects were considered for association analysis between polymorphisms and growth traits. The following general linear models (GLMs) using univariate analysis were used to perform association analyses 
for least squares means (LSMs) with statistical analysis software (SAS) 9.1 .3 (SAS Institute Inc., Cary, NC, USA) including Tukey's HSD post hoc test to separate means. Simultaneously descriptive statistic and standard error of LSMs were analyzed using the statistical package for the social sciences (SPSS) version 16.0 (SPSS Inc., Chicago, IL, USA).

$$
\begin{aligned}
& Y_{i j k}=\mu+G_{i}+B_{j}+G_{i} * B_{j}+e_{i j k} . \\
& Y_{i j k}=\mu+D_{i}+B_{j}+D_{i} * B_{j}+e_{i j k} .
\end{aligned}
$$

Where, $Y=$ the traits measured in chickens, $\mu=$ the population mean, $G=$ effect of genotype, $B$ = effect of breed, $D=$ effect of diplotype, $G^{*} B=$ interaction between genotype and breed, $D^{*} B=$ interaction between diplotype and breed, and $\mathrm{e}=$ random residual error.

\section{RESULTS}

\section{Polymorphisms in the chicken GJA1 gene and their genotyping}

Four previously unknown variants were identified in GJA1. The polymorphisms were located (relative to the ATG start codon) in exon (C61223231T or C.-1110C>T), intron (A61229799C or C.5460A $>C$ and T61229928A or C.5589T $>A$ ), and promoter (A61230599C or c.6260A $>C$ ) regions, in which C61223231T was a synonymous mutation. The genotypes of those SNP sites were determined using HRM analysis (C61223231T) and DNA sequencing (A61229799C, T61229928A and A61230599C). HRM analysis can identify variations in nucleic acid sequences by improved dsDNA-binding dyes. Therefore, one variant was genotyped by the post-PCR method.

\section{Genotypic and allelic frequencies of different variants of the GJA1 gene}

Genotypic and allelic frequencies of four variants of the chicken GJA1 gene are presented in Table 3. At the C61223231T locus, the heterozygous CT genotype was dominant $(51.2 \%)$, which was followed by the CC and TT genotypes in the BJY breed, and C was identified as an advantageous allele in both breeds. Some dominancy was observed for the AC heterozygous in A61229799C mutation, followed by the AA and CC genotypes including the advantageous allele A (64\%) in Cobb chicken population than Beijing-You. The frequency of the homozygous AA genotype was highest in the T61229928A mutation in both BJY and CB breeds, with A being the predominant allele. In the A61230599C polymorphism, the heterozygous AC genotype was dominant (44.1\%) followed by AA and CC genotypes in the BJY breed, whereas the homozygous AA genotype was dominant $(50 \%)$ in the $C B$ chicken population. In both breeds of the A61230599C variant, A was identified as the predominant allele over $\mathrm{C}$. The $\mathrm{X}^{2}$ test showed that the genotypic distribution of two chicken populations among different variants were consistent with HWE $(P>0.05)$, except for the T61229928A mutation in the BJY population, where the TT and TA genotypes were not available.

\section{Association between GJA1 polymorphisms and growth traits}

The descriptive statistics regarding growth traits are presented in Table 4. The results indicated a positive correlation $(r=0.07-0.99)$ between each pair of the five measured traits and their percentages. The highest correlations were observed between BW and CW, BW and EW, and $\mathrm{CW}$ and $\mathrm{EW}$, followed by $\mathrm{CW}$ and $\mathrm{BMW}$, and EW and BMW traits, where the lowest value 
was identified between BW and TMW (\%). Association analysis between different GJA1 variant genotypes and chicken growth traits are presented in Table 5. A significant association was observed between the three genotypes of the C61223231T polymorphism and all growth traits except for BMW. The TT genotypes for all traits were found to have lower mean values than the CC and CT genotypes. Genotypes of the A61229799C variant had only a significant association with the TMW trait. The polymorphism T61229928A had highly significant associations with all growth traits except for TMW. In this variant, TA genotypes showed higher mean values than the AA genotype, and the homozygous TT genotype was not available. Genotypes of the A61230599C variant had a significant association with the CW, BMW, and TMW traits. Lower mean values were found for the $\mathrm{CC}$ genotype than for the $\mathrm{AC}$ and $\mathrm{AA}$ genotypes for all growth traits of the A61230599C mutation.

Table 3. Genotype and allele frequencies of four variants in the chicken GJA1 gene.

\begin{tabular}{|c|c|c|c|c|c|c|c|c|c|}
\hline \multirow{2}{*}{$\begin{array}{l}\text { SNP (location) } \\
\text { C61223231T (Exon) }\end{array}$} & \multirow[t]{2}{*}{ Breed } & \multirow[t]{2}{*}{$\mathrm{N}$} & \multicolumn{3}{|c|}{ Genotype frequency } & \multicolumn{2}{|c|}{ Allele frequency } & \multirow[t]{2}{*}{$\mathrm{X}^{2}(\mathrm{HWE})$} & \multirow[t]{2}{*}{$P$ value } \\
\hline & & & $\mathrm{CC}$ & CT & TT & C & $\mathrm{T}$ & & \\
\hline & Beijing-You & 158 & $0.316(50)$ & $0.512(81)$ & $0.170(27)$ & $0.573(181)$ & $0.427(135)$ & 0.357 & 0.550 \\
\hline & Cobb & 111 & $0.514(57)$ & 0.441 (49) & $0.045(5)$ & $0.734(163)$ & $0.266(59)$ & 1.910 & 0.167 \\
\hline \multirow[t]{3}{*}{ A61229799C (Intron) } & & & $\mathrm{AA}$ & $A C$ & $\mathrm{CC}$ & $A$ & C & & \\
\hline & Beijing-You & 158 & $0.253(40)$ & $0.456(72)$ & $0.291(46)$ & $0.481(152)$ & $0.519(164)$ & 1.200 & 0.273 \\
\hline & Cobb & 111 & $0.387(43)$ & $0.505(56)$ & $0.108(12)$ & $0.640(142)$ & $0.360(80)$ & 0.988 & 0.320 \\
\hline \multirow[t]{3}{*}{ T61229928A (Intron) } & & & TT & TA & $A A$ & $\mathrm{~T}$ & A & & \\
\hline & Beijing-You & 158 & $0(0)$ & $0(0)$ & $1(158)$ & $0(0)$ & $1(316)$ & - & - \\
\hline & Cobb & 111 & $0(0)$ & $0.144(16)$ & $0.856(95)$ & $0.072(16)$ & $0.928(206)$ & 0.670 & 0.413 \\
\hline \multirow[t]{3}{*}{ A61230599C (Promoter) } & & & AA & $\mathrm{AC}$ & $\mathrm{CC}$ & A & C & & \\
\hline & Beijing-You & 152 & $0.382(58)$ & $0.441(67)$ & $0.178(27)$ & $0.602(183)$ & $0.398(121)$ & 0.977 & 0.323 \\
\hline & Cobb & 94 & $0.500(47)$ & $0.436(41)$ & $0.064(6)$ & $0.718(135)$ & $0.282(53)$ & 0.562 & 0.454 \\
\hline
\end{tabular}

HWE = Hardy-Weinberg equilibrium.

Further genotypic association analyses (excluding the breed effect) were conducted for non-significant traits of each GJA1 polymorphism and individual chicken breeds, except for T61229928A, to determine whether or not those variants had a dominant effect on specific chicken populations (Table 6). Genotypes of the C61223231T polymorphism had a more significant association with the BMW trait in the BJY breed than in the CB breed. Similar effects were identified for the A61229799C mutation with the EW and BMW traits, but no breed specific effects were detected for the A61230599C locus in association with the BW and EW traits.

Table 4. Descriptive statistics of growth traits $(\mathrm{g})$ and correlation analysis.

\begin{tabular}{|c|c|c|c|c|c|c|c|c|c|c|c|c|c|}
\hline Traits $(\mathrm{N})$ & Mean & SEM & Min & Max & BW & $\mathrm{CW}$ & EW & BMW & TMW & CW (\%) & EW (\%) & BMW (\%) & TMW (\%) \\
\hline BW (258) & 1909.90 & 36.34 & 924.00 & 3195.00 & 1 & & & & & & & & \\
\hline CW (261) & 1620.44 & 35.37 & 786.00 & 2938.00 & $0.99^{\star \star \star}$ & 1 & & & & & & & \\
\hline EW (253) & 1369.31 & 32.27 & 666.00 & 2654.00 & $0.99^{* \star *}$ & $0.99^{\star \star \star}$ & 1 & & & & & & \\
\hline BMW (254) & 137.55 & 5.95 & 36.00 & 377.00 & $0.96^{\star \star \star}$ & $0.97^{\star \star \star}$ & $0.97^{\star \star \star}$ & 1 & & & & & \\
\hline TMW (254) & 127.55 & 2.77 & 50.00 & 272.20 & $0.91^{* \star *}$ & $0.92^{\star \star *}$ & $0.92^{* * *}$ & $0.90^{\star \star *}$ & 1 & & & & \\
\hline CW $(\%, 250)$ & 85.34 & 0.34 & 72.78 & 121.92 & $0.63^{* \star *}$ & $0.71^{\star \star *}$ & $0.69^{* \star *}$ & $0.70^{\star \star \star}$ & $0.63^{* * *}$ & 1 & & & \\
\hline EW $(\%, 242)$ & 72.27 & 0.38 & 60.74 & 105.44 & $0.70^{\star \star \star}$ & $0.76^{\star \star \star}$ & $0.79^{\star \star \star}$ & $0.77^{\star \star \star}$ & $0.71^{\star \star \star}$ & $0.91^{\star \star \star}$ & 1 & & \\
\hline BMW $(\%, 243)$ & 6.72 & 0.18 & 2.59 & 12.49 & $0.88^{\star \star \star}$ & $0.91^{\star \star \star}$ & $0.91^{* \star *}$ & $0.97^{\star \star \star}$ & $0.83^{\star \star \star}$ & $0.75^{\star \star \star}$ & $0.80^{* * *}$ & 1 & \\
\hline TMW $(\%, 243)$ & 6.81 & 0.06 & 3.46 & 11.30 & 0.07 & 0.09 & 0.11 & 0.09 & $0.44^{* \star *}$ & $0.27^{\star \star \star}$ & $0.29^{\star \star *}$ & 0.11 & 1 \\
\hline
\end{tabular}

$\mathrm{SEM}=$ Standard error of the mean; $\mathrm{BW}=$ body weight before slaughter; $\mathrm{CW}=$ carcass weight; $\mathrm{EW}=$ evisceration weight, $\mathrm{BMW}=$ breast muscle weight; TMW = thigh muscle weight; $\%=$ percentage; ${ }^{* * *}=\mathrm{P}<0.001$. 


\begin{tabular}{|c|c|c|c|c|c|}
\hline SNP (location) & Trait (N) & & Genotype & & $P$ value \\
\hline \multirow[t]{6}{*}{ C61223231T (Exon) } & & $\mathrm{CC}$ & CT & TT & \\
\hline & BW (258) & $1984.15 \pm 26.44^{b}(102)$ & $2017.10 \pm 24.29^{c}(125)$ & $1810.94 \pm 64.74^{\mathrm{a}}(31)$ & 0.012 \\
\hline & CW (261) & $1737.14 \pm 22.50^{\mathrm{b}}(103)$ & $1755.96 \pm 21.07^{\circ}(127)$ & $1577.57 \pm 61.13^{\mathrm{a}}(31)$ & 0.024 \\
\hline & EW (253) & $1500.39 \pm 21.48^{\mathrm{c}}(98)$ & $1496.66 \pm 20.06^{\mathrm{b}}(124)$ & $1338.62 \pm 56.96^{\mathrm{a}}(31)$ & 0.026 \\
\hline & BMW (254) & $161.25 \pm 3.23(99)$ & $160.10 \pm 3.03(124)$ & $142.83 \pm 8.61(31)$ & 0.132 \\
\hline & TMW (254) & $138.32 \pm 2.66^{b}(99)$ & $137.43 \pm 2.50^{\mathrm{b}}(124)$ & $114.77 \pm 7.08^{\mathrm{a}}(31)$ & 0.007 \\
\hline \multirow[t]{6}{*}{ A61229799C (Intron) } & & AA & $\mathrm{AC}$ & $\mathrm{CC}$ & \\
\hline & BW (258) & $1986.67 \pm 30.29(80)$ & $2000.56 \pm 24.54(122)$ & $1940.39 \pm 43.99(56)$ & 0.491 \\
\hline & CW (261) & $1734.13 \pm 26.00(79)$ & $1748.52 \pm 20.91(125)$ & $1705.83 \pm 38.77(57)$ & 0.619 \\
\hline & EW (253) & $1497.65 \pm 24.69(75)$ & $1501.80 \pm 19.66(122)$ & $1410.99 \pm 37.27(56)$ & 0.088 \\
\hline & BMW (254) & $160.69 \pm 3.74(75)$ & $159.74 \pm 2.96(123)$ & $157.00 \pm 5.65(56)$ & 0.862 \\
\hline & TMW (254) & $140.45 \pm 3.06^{b}(75)$ & $137.00 \pm 2.42^{\mathrm{b}}(123)$ & $123.06 \pm 4.62^{\mathrm{a}}(56)$ & 0.007 \\
\hline \multirow{6}{*}{ T61229928A (Intron) } & & $\mathrm{TT}$ & TA & AA & \\
\hline & BW (258) & & $2264.50 \pm 65.70(16)$ & $2002.95 \pm 17.30(242)$ & 0.000 \\
\hline & CW (261) & & $2060.00 \pm 62.60(13)$ & $1747.92 \pm 14.90(248)$ & 0.005 \\
\hline & EW (253) & & $1820.62 \pm 58.81(13)$ & $1496.23 \pm 14.39(240)$ & 0.009 \\
\hline & BMW (254) & & $225.32 \pm 8.77(13)$ & $161.18 \pm 2.14(241)$ & 0.002 \\
\hline & TMW (254) & & $162.65 \pm 7.43(13)$ & $136.79 \pm 1.81(141)$ & 0.175 \\
\hline \multirow[t]{6}{*}{ A61230599C (Promoter) } & & AA & $A C$ & $\mathrm{CC}$ & \\
\hline & BW (236) & $1961.65 \pm 26.02(100)$ & $2000.94 \pm 26.06(104)$ & $1854.26 \pm 58.82(32)$ & 0.070 \\
\hline & CW (241) & $1726.51 \pm 21.98^{\mathrm{b}}(103)$ & $1744.47 \pm 22.29^{\mathrm{b}}(106)$ & $1599.30 \pm 53.88^{\mathrm{a}}(32)$ & 0.047 \\
\hline & EW (233) & $1486.60 \pm 21.34(98)$ & $1490.59 \pm 21.53$ & $1360.86 \pm 50.73(32)$ & 0.056 \\
\hline & BMW (234) & $160.85 \pm 3.23^{\mathrm{b}}(98)$ & $159.42 \pm 3.23^{b}(104)$ & $140.15 \pm 7.68^{\mathrm{a}}(32)$ & 0.044 \\
\hline & TMW (234) & $136.20 \pm 2.61^{\mathrm{b}}(98)$ & $135.88 \pm 2.61^{\mathrm{b}}(104)$ & $117.88 \pm 6.20^{\mathrm{a}}(32)$ & 0.021 \\
\hline
\end{tabular}

LSM = least squares mean; SEM = standard error of the mean; BW = body weight before slaughter; CW = carcass weight; $\mathrm{EW}=$ evisceration weight, $\mathrm{BMW}$ = breast muscle weight; $\mathrm{TMW}=$ thigh muscle weight. Mean values bearing different letters $(a, b$, or $c)$ in each row are significantly different $(P<0.05)$.

\section{Haplotype and diplotype analysis of the GJA1 gene}

Haplotype block and LD structures were generated from the four SNPs genotyped in the GJA1 gene from chicken (Figure 1). Only two variants, C61223231T (exon) and A61229799C (intron), showed significant LD with each other $\left(r^{2}=0.94\right)$, spanning a 6 -kb block. Therefore, haplotypes were constructed from these two polymorphic sites of GJA1 (Table 7) and their haplotype combinations, or diplotypes, (Table 8) were prepared to study the association with growth traits. A total of four haplotypes and seven diplotypes were discovered in the GJA1 gene, where the CA haplotype showed the highest frequency (53.7\%), followed by TC (35.1\%) and CC $(10.2 \%)$. In the diplotype study, the highest frequency was observed for the TC+CA (37.9\%) diplotype, followed by CA+CA $(29 \%)$ and TC+TC (11.9\%).

\section{Association analysis of GJA1 diplotypes and growth traits of chicken}

Association analysis was performed between diplotype of the GJA1 gene and chicken growth traits (Table 8), which revealed that BW, EW, and TMW traits were more highly significant than CW and BMW traits. The highest and lowest mean values of BW, CW, EW BMW, and TMW traits were found to belong to the $\mathrm{CC}+\mathrm{CC}$ and $\mathrm{TC}+\mathrm{TC}$ diplotypes, respectively. 


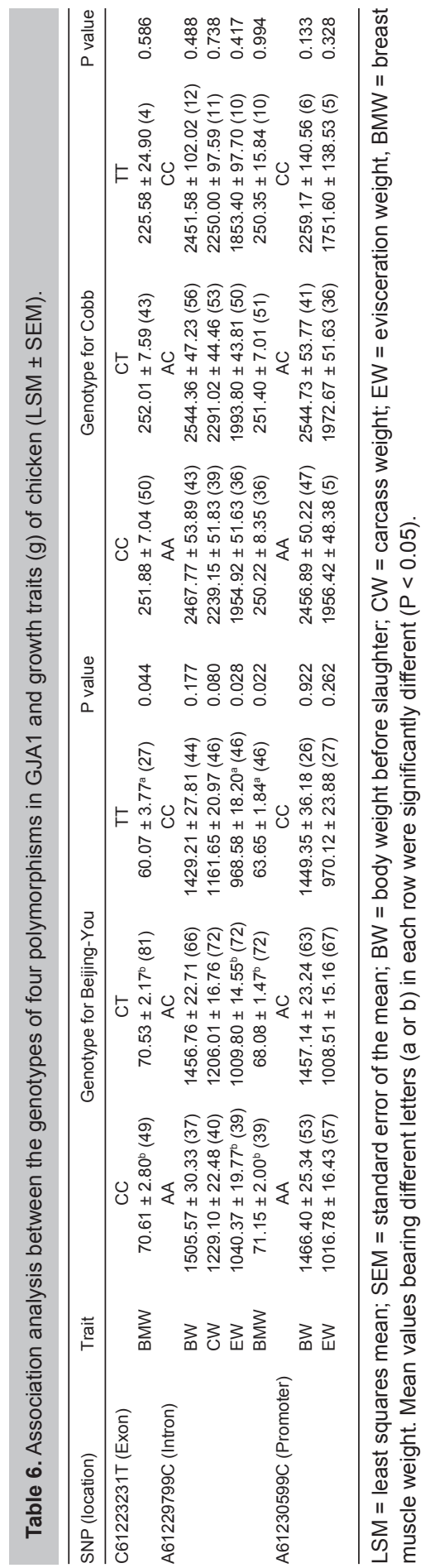




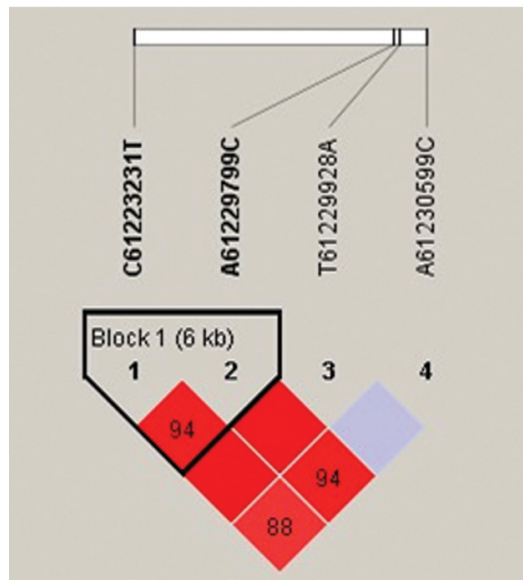

Figure 1. Linkage disequilibrium (LD) of single nucleotide polymorphisms (SNPs) in the chicken GJA1 gene. Pairwise (r2) values are shown between polymorphisms, which were calculated from the genotypic data of 269 chickens. The haplotype block was defined by using the default setting of the Haploview software.

Table 7. Frequency of haplotypes based on linkage disequilibrium (LD) in the GJA1 gene.

\begin{tabular}{lccc}
\hline SNP & Haplotype & Observation & Frequency \\
\hline C61223231T and A61229799C & CA & 289 & 0.537 \\
& TC & 189 & 0.351 \\
& CC & 55 & 0.102 \\
& TA & 5 & 0.009 \\
\hline
\end{tabular}

Table 8. Association analysis between diplotypes of the GJA1 gene and growth traits ( $\mathrm{g}$ ) of chicken (LSM \pm SEM).

\begin{tabular}{|c|c|c|c|c|c|c|}
\hline Diplotype & $\begin{array}{l}\text { Frequency } \\
\text { (observation) }\end{array}$ & BW & $\mathrm{CW}$ & EW & BMW & TMW \\
\hline $\mathrm{TC}+\mathrm{TC}$ & $0.119(32)$ & $1810.94 \pm 64.30^{\mathrm{a}}(31)$ & $1577.57 \pm 60.71^{\mathrm{a}}(31)$ & $1338.62 \pm 55.78^{\mathrm{a}}(31)$ & $142.83 \pm$ & $114.77 \pm 6.91^{\mathrm{a}}(31)$ \\
\hline $\mathrm{TC}+\mathrm{CC}$ & $0.085(23)$ & $1976.42 \pm 63.04^{\mathrm{ab}}(22)$ & $1728.91 \pm 53.81^{\mathrm{ab}}(23)$ & $1385.21 \pm 52.97^{\mathrm{ab}}(22)$ & $157.52 \pm 8.01^{\mathrm{ab}}(22)$ & $120.00 \pm 6.56^{a}(22)$ \\
\hline $\mathrm{TC}+\mathrm{CA}$ & $0.379(102)$ & $2018.93 \pm 26.97^{\mathrm{bc}}(98)$ & $1762.95 \pm 23.23^{\text {bod }}(100)$ & $1511.05 \pm 21.70^{\text {bod }}(98)$ & $159.42 \pm 3.28^{\mathrm{abc}}(98)$ & $139.59 \pm 2.69^{\mathrm{bc}}(98)$ \\
\hline $\mathrm{TA}+\mathrm{CA}$ & $0.019(5)$ & $2138.00 \pm 120.21^{\mathrm{bc}}(5)$ & $1739.67 \pm 130.85^{\mathrm{abc}}(4)$ & $1591.53 \pm 120.23^{\mathrm{abc}}(4)$ & $198.20 \pm 18.18^{\text {bc }}(4)$ & $154.13 \pm 14.89^{\text {abc }}(4)$ \\
\hline $\mathrm{CC}+\mathrm{CC}$ & $0.011(3)$ & $2452.50 \pm 161.27^{\circ}(3)$ & $2159.75 \pm 138.79^{d}(3)$ & $1911.78 \pm 127.52^{\mathrm{d}}(3)$ & $221.95 \pm 19.29^{c}(3)$ & $177.30 \pm 15.79^{\circ}(3)$ \\
\hline $\mathrm{CC}+\mathrm{CA}$ & $0.097(26)$ & $1946.13 \pm 55.52^{\mathrm{bc}}(24)$ & $1702.44 \pm 45.66^{\text {cd }}(25)$ & $1472.53 \pm 42.66^{\mathrm{cd}}(24)$ & $160.45 \pm 6.35^{\mathrm{abc}}(25)$ & $130.08 \pm 5.20^{\mathrm{bc}}(25)$ \\
\hline $\mathrm{CA}+\mathrm{CA}$ & $0.290(78)$ & $1979.94 \pm 30.54^{\text {bc }}(75)$ & $1735.07 \pm 26.17^{\text {bod }}(75)$ & $1495.88 \pm 24.72^{\mathrm{cd}}(71)$ & $159.54 \pm 3.74^{\text {bc }}(71)$ & $140.14 \pm 3.06^{\mathrm{bc}}(71)$ \\
\hline$P$ value & & 0.004 & 0.008 & 0.001 & 0.005 & 0.000 \\
\hline
\end{tabular}

LSM = least squares mean; SEM = standard error of the mean; BW = body weight before slaughter; $\mathrm{CW}=$ carcass weight; $\mathrm{EW}=$ evisceration weight, $\mathrm{BMW}=$ breast muscle weight; $\mathrm{TMW}=$ thigh muscle weight. Mean values bearing different letters $(a, b, c$, or $d)$ in each column are significantly different $(P<0.05)$.

\section{DISCUSSION}

Skeletal muscle tissues are comprised of different cell types, in which various genes encoding regulatory factors are involved in the formation of muscle (Buckingham et al., 2003). For this reason, the genetic basis of protein formation in chicken will provide an opportunity for genetic improvement of traits associated with muscle development. Therefore, the study of candidate genes is one of the primary methods (Zhang et al., 2009) to determine whether a gene of interest is associated with selected economic traits. 
In the present study, we identified four unknown SNPs, one of which was located in an exon region, two of which were in an intron region, and one that was in the promoter region of the chicken GJA1 gene. The SNP located in exon was genotyped by HRM analysis due to its higher sensitivity and specificity (Garritano et al., 2009) compared with other methods. Genotypic and allelic frequencies, and breed-specific association studies of polymorphisms in chicken GJA1, indicate that the Chinese indigenous chicken breed BJY has higher genetic variation than the commercial CB strain. This reveals that the commercial breed is undergoing long-term artificial selection, which leads to a reduction in the negative allele frequency (Andersson, 2001). Therefore, homozygosity dominated the different GJA1 variants found in the CB population, which suggests the accumulation of this desired allele for meat traits, except for the A61229799C variant, which needs further improvement (Wu et al., 2011) for the A allele. It could be speculated that more genetic progress should be expected in indigenous breeds than in commercial breeds in terms of genetic diversity.

The SNP C61223231T found in the GJA1 gene was a synonymous mutant, which was found to have a positive association with the BW, CW, EW, and TMW traits in chicken. Although synonymous polymorphisms do not change the sequence or structure of the protein they encode, they could affect messenger RNA splicing, stability, structure, or protein folding, which significantly affect protein function (Hunt et al., 2009). Genetic polymorphisms in the exon region of the GJA1 gene have been positively associated with various diseases in human (Kogame et al., 2014; Jamsheer et al., 2014), mice (Flenniken et al., 2005), and fish (lovine et al., 2005). No available data associate the chicken GJA1 gene with growth traits, though several studies have been performed on other genes (Sato et al., 2012; Fornari et al., 2014) in chicken and have shown positive correlations with growth traits. Therefore, our discovery of a synonymous mutation in the chicken GJA1 gene and its significant association with growth traits suggests that this polymorphism could be used as a molecular marker for growth or muscle development traits in chicken.

Similarly, the variants detected in intron (A61229799C and T61229928A) and promoter (A61230599C) regions of the GJA1 gene had significant associations with chicken growth traits. Previous studies have shown that transcription factors can bind a few specific sites located in the promoter and intron regions of genes to influence gene expression (Myers et al., 2007; Pereyra et al., 2012) and protein translation (Down et al., 2012). However, the exact functions of SNPs in non-coding regulatory regions are not clear, but are predicted to influence the binding affinity of transcription factors (Kim et al., 2008). Therefore, we hypothesize that the variants identified from our study could disrupt some transcription factor-binding sites (Sheng et al., 2013) that alter GJA1 gene expression and affect muscle development in chicken, although further investigations are required.

LD analysis indicated that the C61223231T and A61229799C SNPs are a close LD pair, which suggests that these two mutations may consistently be associated with some specific traits of interest. Our results show that these two variants of the GJA1 gene exert a highly additive effect on growth traits of chickens. Therefore, haplotype construction from these two SNPs belonging to a LD block was consistent. Association analysis of haplotype combinations showed highly significant associations with all the growth traits studied. It is apparent that $\mathrm{CC}$ and $\mathrm{CC}+\mathrm{CC}$ may be the most advantageous haplotypes and diplotypes, respectively, which may control growth regulation. As our haplotype block was based on two SNPs, more tag SNPs should be typed (Zhang et al., 2009) in order to detect complete haplotype blocks in different chicken breeds. Haplotype analysis is more powerful in LD studies to resolve noisy and unsatisfying effects than single marker analysis which are caused by diverse marker history and statistical methods, and results monotonic and step-like breakdown 
of LD by recombination (Daly et al., 2001). Haplotype and diplotype analyses of chicken BW, CW, EW, BMW, and TMW traits have previously been studied on different genes (Zhang et al., 2008; Su et al., 2012; Xu et al., 2012). However, this is the first study to report the effect of GJA1 haplotype combinations (diplotype) on economic traits in chicken. Hence, GJA1 may act as a candidate gene of QTL for the regulation of muscle growth in chicken.

In summary, the present study describes four previously unknown SNPs, four haplotypes from two variants having high LD, and seven diplotypes of the chicken GJA1 gene, and reports their significant association with growth traits. These results indicate that GJA1 is positively associated with growth regulation, and the alleles and haplotypes of this gene may serve as genetic markers for future MAS of chicken muscle development. Therefore, the functional study of this gene is essential to explore the biological implication of these polymorphisms. To clarify the variation of studied traits, further research on a large number of chicken samples with different genetic backgrounds is recommended.

\section{Conflicts of interest}

The authors declare no conflict of interest.

\section{ACKNOWLEDGMENTS}

Research supported by the following grants: National High-tech R\&D Program (\#2011AA100301), the Agricultural Science and Technology Innovation Program (\#ASTIP-IAS04), and the earmarked fund for modern agro-industry technology research system (\#CARS-42).

\section{REFERENCES}

Amano K, Ishiguchi M, Aikawa T, Kimata M, et al. (2012). Cleft lip in oculodentodigital dysplasia suggests novel roles for connexin 43. J. Dent. Res. 91: 38S-44S.

Andersson L (2001). Genetic dissection of phenotypic diversity in farm animals. Nat. Rev. Genet. 2: 130-138.

Bai Y, Sun G, Kang X, Han R, et al. (2012). Polymorphisms of the pro-opiomelanocortin and agouti-related protein genes and their association with chicken production traits. Mol. Biol. Rep. 39: 7533-7539.

Barrett JC, Fry B, Maller J and Daly MJ (2005). Haploview: analysis and visualization of LD and haplotype maps. Bioinformatics 21: 263-265.

Buckingham M, Bajard L, Chang T, Daubas P, et al. (2003). The formation of skeletal muscle: from somite to limb. J. Anat. 202: $59-68$

Daly MJ, Rioux JD, Schaffner SF, Hudson TJ, et al. (2001). High-resolution haplotype structure in the human genome. Nat. Genet. 29: 229-232.

Dodgson JB, Cheng HH and Okimoto R (1997). DNA marker technology: a revolution in animal genetics. Poult. Sci. 76: 1108-1114.

Down CF, Millour J, Lam EW and Watson RJ (2012). Binding of FoxM1 to G2/M gene promoters is dependent upon B-Myb. Biochim. Biophys. Acta. 1819: 855-862.

Emara MG and Kim H (2003). Genetic markers and their application in poultry breeding. Poult. Sci. 82: 952-957.

Fang M, Nie Q, Luo C, Zhang D, et al. (2010). Associations of GHSR gene polymorphisms with chicken growth and carcass traits. Mol. Biol. Rep. 37: 423-428.

Flenniken AM, Osborne LR, Anderson N, Ciliberti N, et al. (2005). A Gja1 missense mutation in a mouse model of oculodentodigital dysplasia. Development 132: 4375-4386.

Fornari MB, Zanella R, Ibelli AM, Fernandes LT, et al. (2014). Unraveling the associations of osteoprotegerin gene with production traits in a paternal broiler line. Springerplus. 3: 682

Garritano S, Gemignani F, Voegele C, Nguyen-Dumont T, et al. (2009). Determining the effectiveness of High Resolution Melting analysis for SNP genotyping and mutation scanning at the TP53 locus. BMC Genet. 10: 5.

Gu X, Feng C, Ma L, Song C, et al. (2011). Genome-wide association study of body weight in chicken F2 resource population. PLoS One 6: e21872. 
Hou X, Han R, Tian Y, Xie W, et al. (2013). Cloning of TPO gene and associations of polymorphisms with chicken growth and carcass traits. Mol. Biol. Rep. 40: 3437-3443.

Hunt R, Sauna ZE, Ambudkar SV, Gottesman MM, et al. (2009). Silent (synonymous) SNPs: should we care about them? Methods Mol. Biol. 578: 23-39.

lovine MK, Higgins EP, Hindes A, Coblitz B, et al. (2005). Mutations in connexin43 (GJA1) perturb bone growth in zebrafish fins. Dev. Biol. 278: 208-219.

Jamsheer A, Sowińska-Seidler A, Socha M, Stembalska A, et al. (2014). Three novel GJA1 missense substitutions resulting in oculo-dento-digital dysplasia (ODDD) - further extension of the mutational spectrum. Gene 539: 157-161.

Kerje S, Carlborg Ö, Jacobsson L, Schütz K, et al. (2003). The twofold difference in adult size between the red junglefowl and White Leghorn chickens is largely explained by a limited number of QTLs. Anim. Genet. 34: 264-274.

Kim BC, Kim WY, Park D, Chung WH, et al. (2008). SNP@ Promoter: a database of human SNPs (single nucleotide polymorphisms) within the putative promoter regions. BMC Bioinformatics 9: S2.

Kogame T, Dainichi T, Shimomura Y, Tanioka M, et al. (2014). Palmoplantar keratosis in oculodentodigital dysplasia with a GJA1 point mutation out of the C-terminal region of connexin 43. J. Dermatol. 41: 1095-1097.

Li WJ, Zhao GP, Chen JL, Zheng MQ, et al. (2009). Influence of dietary vitamin E supplementation on meat quality traits and gene expression related to lipid metabolism in the Beijing-you chicken. Br. J. Poult. Sci. 50: 188-198.

Liu R, Sun Y, Zhao G, Wang F, et al. (2013). Genome-wide association study identifies loci and candidate genes for body composition and meat quality traits in Beijing-You chickens. PloS One 8: e61172.

Myers RL, Airey DC, Manier DH, Shelton RC, et al. (2007). Polymorphisms in the regulatory region of the human serotonin 5-HT 2A receptor gene (HTR2A) influence gene expression. Biol. Psychiatry 61: 167-173.

Nie QH, Fang MX, Xie L, Shen X, et al. (2010). Associations of ATGL gene polymorphisms with chicken growth and fat traits. J. Appl. Genet. 51: 185-191.

Nones K, Ledur MC, Ruy DC, Baron EE, et al. (2006). Mapping QTLs on chicken chromosome 1 for performance and carcass traits in a broiler x layer cross. Anim. Genet. 37: 95-100.

Pereyra S, Velazquez T, Bertoni B and Sapiro R (2012). Rapid multiplex high resolution melting method to analyze inflammatory related SNPs in preterm birth. BMC Res. Notes 5: 69.

Pinard-van der Laan MH, Bed'hom B, Coville JL, Pitel F, et al. (2009). Microsatellite mapping of QTLs affecting resistance to coccidiosis (Eimeria tenella) in a Fayoumi $x$ White Leghorn cross. BMC Genomics 10: 31.

Sato S, Ohtake T, Uemoto Y, Okumura Y, et al. (2012). Polymorphism of insulin-like growth factor 1 gene is associated with breast muscle yields in chickens. Anim. Sci. J. 83: 1-6.

Sheng Q, Cao D, Zhou Y, Lei Q, et al. (2013). Detection of SNPs in the Cathepsin D Gene and Their Association with Yolk Traits in Chickens. PloS One 8: e56656.

Stephens M, Smith NJ and Donnelly P (2001). A new statistical method for haplotype reconstruction from population data. Am. J. Hum. Genet. 68: 978-989.

Su L, Wang SH, Han RL, Sun GR, et al. (2012). Polymorphisms of the PNPLA3 gene and their associations with chicken growth and carcass traits. Br. Poult. Sci. 53: 453-459.

Sun Y, Liu R, Lu X, Hu Y, et al. (2013). Associations of polymorphisms in four candidate genes with carcass and/or meat-quality traits in two meat-type chicken lines. Anim. Biotechnol. 24: 53-65.

Vignal A, Milan D, SanCristobal M and Eggen A (2002). A review on SNP and other types of molecular markers and their use in animal genetics. Genet. Sel. Evol. 34: 275-306.

Wang SZ, Hu XX, Wang ZP, Li XC, et al. (2012). Quantitative trait loci associated with body weight and abdominal fat traits on chicken chromosomes 3, 5 and 7. Genet. Mol. Res.11: 956-965.

Wu W, Zuo B, Ren Z, Hapsari AA, et al. (2011). Identification of four SNPs and association analysis with meat quality traits in the porcine Pitx2c gene. Sci. China Life Sci. 54: 426-433.

Xie L, Luo C, Zhang C, Zhang R, et al. (2012). Genome-wide association study identified a narrow chromosome 1 region associated with chicken growth traits. PLoS One. 7: e30910.

Xu HY, Wang Y, Liu YP, Wang JW, et al. (2012). Polymorphisms and expression of the chicken POU1F1 gene associated with carcass traits. Mol. Biol. Rep. 39: 8363-8371.

Zhang ZR, Liu YP, Jiang X, Du HR, et al. (2008). Study on association of single nucleotide polymorphism of CAPN1 gene with muscle fibre and carcass traits in quality chicken populations. J. Anim. Breed. Genet. 125: 258-264.

Zhang ZR, Liu YP, Yao YG, Jiang XS, et al. (2009). Identification and association of the single nucleotide polymorphisms in calpain3 (CAPN3) gene with carcass traits in chickens. BMC Genet. 10: 10. 